\title{
Uptake of Triiodothyronine Sulfate and Suppression of Thyrotropin Secretion in Cultured Anterior Pituitary Cells
}

\author{
M.E. Everts, T.J. Visser, J.C.J. van Buuren, R. Docter, M. de Jong, E.P. Krenning, and G. Hennemann
}

To investigate the uptake of triiodothyronine sulfate $\left(\mathrm{T}_{3} \mathrm{~S}\right)$ and its effect on thyrotropin-releasing hormone (TRH)-induced thyrotropin (TSH) secretion, anterior pituitary cells were isolated from euthyroid rats and cultured for 3 days in medium containing $10 \%$ fetal calf serum. Incubation was performed at $37^{\circ} \mathrm{C}$ in medium containing $0.5 \%$ bovine serum albumin (BSA). Exposure of the pituitary cells to TRH $(0.1 \mu \mathrm{mol} / \mathrm{L})$ for 2 hours stimulated TSH secretion by $176 \%$. This effect was reduced by approximately $45 \%$ after a 2-hour preincubation with $T_{3}(0.001$ to $1 \mu \mathrm{mol} / \mathrm{L})$. A significant inhibitory effect of $\mathrm{T}_{3} \mathrm{~S}$ on TRH-induced TSH release was only observed at a concentration of $1 \mu \mathrm{mol} / \mathrm{L}$. The uptake of [ $\left.{ }^{125}\right]_{]} \mathrm{T}_{3}$ after 1 hour of incubation was reduced by $40 \% \pm 4 \%(P<.001)$ by simultaneous addition of $10 \mathrm{nmol} / \mathrm{L}$ unlabeled $\mathrm{T}_{3}$, whereas $1 \mu \mathrm{mol} / \mathrm{L} \mathrm{T}_{3} \mathrm{~S}$ was required to obtain a reduction of the $\left[{ }^{125} \mid\right] \mathrm{T}_{3}$ uptake by $34 \% \pm 2 \%(P<.001)$. The amount of $\mathrm{T}_{3}$ present in the unlabeled $\mathrm{T}_{3} \mathrm{~S}$ preparation was $0.25 \%$ as determined by radioimmunoassay. When pituitary cells were incubated for 1 hour with [ $\left.\left.{ }^{125}\right)\right]_{3} \mathrm{~T}_{3}$ or $\left[{ }^{125} \mid \mathrm{T}_{3}(\mathrm{both}\right.$ $50,000 \mathrm{cpm} / 0.25 \mathrm{~mL}$ ), the uptake of $\left.\left[{ }^{125}\right)\right] \mathrm{T}_{3} \mathrm{~S}$ expressed as a percentage of the dose was $0.04 \% \pm 0.02 \%$ (mean $\pm \mathrm{SE}, \mathrm{n}=4$ ), whereas that of $\left.{ }^{125} \mid\right]_{3}$ amounted to $3.0 \% \pm 0.4 \%(n=4)$. In contrast, when hepatocytes were incubated for 1 hour with $\left[{ }^{125} \mid\right] \mathrm{T}_{3} \mathrm{~S}$, the uptake amounted to $5.1 \% \pm 0.8 \%(\mathrm{n}=9)$, whereas that of $\left[{ }^{125} \mid\right] \mathrm{T}_{3}$ was $22.1 \% \pm 1.7 \%(\mathrm{n}=9)$. Furthermore, $\left[{ }^{125} \mid\right] \mathrm{T}_{3} \mathrm{~S}$ was as rapidly deiodinated (iodide production, $14.9 \% \pm 2.6 \% ; n=9)$ as $\left[{ }^{125} \mid\right]_{3}(12.1 \% \pm 0.8 \%, n=9)$ by hepatocytes. It is concluded that (1) $\mathrm{T}_{3} \mathrm{~S}$ is poorly taken up by pituitary cells, and (2) the suppressive effect of high concentrations of $T_{3} S$ on TRH-induced TSH secretion and on [ $\left.{ }^{125} \mid\right] T_{3}$ uptake can be explained by slight contamination with $T_{3}$. Thus, it appears that $T_{3} S$ has only a minor biological effect, if any, on the pituitary.

Copyright 1994 by W.B. Saunders Company

QU LFATION plays a significant role in the metabolism of iodothyronines in both man and animals, although it is probably more important for triioduthyronine $\left(\mathrm{T}_{3}\right)$ than for thyroxine, at least in rats and dogs. ${ }^{1-3}$ However, during nonthyroidal illness (NTI) the contribution of the different pathways, ie, deiodination, glucuronidation, and sulfation, to thyroid hormone metabolism might change considerably. ${ }^{4,5}$ Measurements of the hormone levels in sera of NTI patients showed that the reduction in serum $T_{3}$ and thyroxine was accompanied by a threefold increase in serum $\mathrm{T}_{3}$ sulfate $\left(\mathrm{T}_{3} \mathrm{~S}\right)$ apart from the known increase in serum reverse $\mathbf{T}_{3}{ }^{6}$ Despite these changes, serum thyrotropin (TSH) was in the normal range. ${ }^{6}$

In the study by LoPresti et al, ${ }^{7}$ the question was raised as to whether the increased $\mathrm{T}_{3} \mathrm{~S}$ production might contribute to the suppression of TSH secretion during NTI. In their experiments, infusion of $\mathrm{T}_{3} \mathrm{~S}$ in healthy volunteers, calculated to result in a relatively low serum level of $\mathrm{T}_{3} \mathrm{~S}$, did not reduce the serum TSII level. ${ }^{7}$ In another study with the growth hormone-producing pituitary tumor cell line $\mathrm{GH}_{4} \mathrm{C}_{1}$, it was shown that $\mathrm{T}_{3} \mathrm{~S}$ failed to displace $\left[{ }^{125} \mathrm{I}\right] \mathrm{T}_{3}$ from the nuclear binding sites. ${ }^{8}$ However, the possibility that $\mathrm{T}_{3} \mathrm{~S}$ could have thyromimetic activity after desulfation was not excluded. ${ }^{8.9}$ More recently, it was reported that administration of $\mathrm{T}_{3} \mathrm{~S}$ to hypothyroid rats produced thyromimetic

From the Departments of Internal and Nuclear Medicine, Erasmus University Medical School, Rotterdam, The Netherlands.

Submitted August 5, 1993; accepted December 16, 1993.

Supported by the Trustfonds of the Erasmus University Rotterdam. The Netherlands. M.E.E. holds a fellowship from the Royal Netherlands Academy of Arts and Sciences.

Address reprint requests to M.E. Everts, PhD, Department of Internal Medicine III, Erasmus University Medical School, Postbox 1738, NL-3000 DR Rotterdam, The Netherlands.

Copyright 11994 by W.B. Saunders Company

$00260495 / 94 / 43100013 \$ 03.00 / 0$ effects with a potency of approximately $20 \%$ that of $\mathrm{T}_{3 .}{ }^{10} \mathrm{In}$ the same study, it was shown that treatment of hypothyroid rats with a relatively high dose of $\mathrm{T}_{3} \mathrm{~S}$ resulted in a reduction of serum TSH and a normalization of the serum $\mathrm{T}_{3}$ level, indicating desulfation of $\mathrm{T}_{3} \mathrm{~S}$ in vivo. "I

Together, these results could be explained by the assumption that $T_{3} S$ is not taken up by the pituitary, and that the effects of $T_{3} S$ in vivo might be due to an effect of $T_{3}$ (after desulfation or due to contamination of $T_{3} S$ ). To test this hypothesis, the present study was undertaken to examine in vitro the effects of $\mathrm{T}_{3} \mathrm{~S}$ on TSH secretion and the uptake of $\left[{ }^{125} \mathrm{I}\right] \mathrm{T}_{3} \mathrm{~S}$ by the pituitary. We used primary cultures of anterior pituitary cells of euthyroid rats. This preparation contains active thyrotrophs that release TSH in response to (TSH-releasing hormone $[\mathrm{TRH}]$ ) and transport $\mathrm{T}_{3}$ by a carrier-mediated mechanism. " Since it is not known whether $\mathrm{T}_{3} \mathrm{~S}$ is metabolized in the pituitary like it is in the liver ${ }^{12}$ and whether possible effects of $T_{3} S$ on pituitary function should be ascribed to $\mathrm{T}_{3} \mathrm{~S}$ itself or to any metabolic product, we have also compared pituitary cells and hepatocytes with respect to the uptake and deiodination of $\left[{ }^{125} \mathrm{I}\right] \mathrm{T}_{3} \mathrm{~S}$ and $\left[{ }^{125} \mathrm{I}\right] \mathrm{T}_{3}$

\section{MATERIALS AND METHODS}

\section{Animals}

All experiments were performed using male Wistar rats weighing 220 to $250 \mathrm{~g}$. The animals had free access to food and water and were kept in a controlled environment $\left(21^{\circ} \mathrm{C}\right)$ with constant day length ( 12 hours)

\section{Pituitary Cell Culture}

Animals (12 for each experinent) were killed between 9:00 and 9:30 AM by decapitation. The pituitary glands were removed within 5 minutes, the neurointermediate lobe was discarded, and the anterior lobes were collected in calcium- and magnesium-free Hanks balanced salt solution supplemented with $10 \mathrm{~g} / \mathrm{L}$ human serum albumin, penicillin $\left(10^{5} \mathrm{U} / \mathrm{L}\right.$ ), amphotericin $\mathrm{B}$ (Fungizone, 
Bristol-Myers Squibb, Wœrden, The Netherlands; $0.5 \mathrm{mg} / \mathrm{L}$ ), and sodium bicarbonate $(0.4 \mathrm{~g} / \mathrm{L})$. The anterior pituitary lobes were dissociated with dispase $\left(2.4 \times 10^{3} \mathrm{U} / \mathrm{L}\right)$ as described in detail elsewhere ${ }^{13}$ From each pituitary, 1 to $1.5 \times 10^{6}$ cells were obtained, and the viability of the cells as determined by trypan blue exclusion was greater than $90 \%$.

The cells were cultured at $37^{\circ} \mathrm{C}$ in a water-jacketed incubator in humidified air with $5 \% \mathrm{CO}_{2}$ at a density of 3 to $5 \times 10^{5}$ cells per well in 48-well culture dishes. The culture medium consisted of Minimal Essential Medium with Earle's salts supplemented with nonessential amino acids, sodium pyruvate ( $1 \mathrm{mmol} / \mathrm{L}), 10 \%$ fetal calf serum, penicillin $\left(10^{5} \mathrm{U} / \mathrm{L}\right)$, amphotericin $B(0.5 \mathrm{mg} / \mathrm{L})$, l-glutamine $(2 \mathrm{mmol} / \mathrm{L})$, and sodium bicarbonate $(2.2 \mathrm{~g} / \mathrm{L}, \mathrm{pH}$ 7.4). ${ }^{13,14}$ The cells had attached to the wells after 2 days of culture; on day 3 , the cells were used for experiments. In a previous study it was shown that the TSH content of the pituitary cell preparation was highest after this short period of culture. ${ }^{\prime \prime}$

\section{TSH Secretion}

The culture medium was removed from the cells, and the cells were washed once with incubation medium. This medium was identical to the culture medium except that the fetal calf serum was replaced by $0.5 \%$ bovine serum albumin (BSA). The pituitary cells were preincubated for 2 hours at $37^{\circ} \mathrm{C}$ in the absence or presence of variable concentrations of $T_{3}$ or $T_{3} S(0.001$ to $1 \mu \mathrm{mol} / \mathrm{L})$. The medium was then discarded, and fresh medium was added containing TRH $(0.1 \mu \mathrm{mol} / \mathrm{L})$ with or without $\mathrm{T}_{3}$ or $\mathrm{T}_{3} \mathrm{~S}$. Incubation was continued for 2 hours at $37^{\circ} \mathrm{C}$ and was followed by removal of the medium. The cells were washed once with $1 \mathrm{~mL}$ ice-cold saline $(0.9 \% \mathrm{NaCl})$. Incubation media were centrifuged $(2,000 \times g)$, and the supernatants were frozen for later determination of TSH. Incubations were performed in triplicate.

\section{Ilepatocytes}

Hepatocytes were isolated by collagenase perfusion as previously described. ${ }^{15} \mathrm{Cells}$ were cultured at $37^{\circ} \mathrm{C}$ at a density of $2 \times 10^{6}$ cells per well in 6-well culture dishes in $2 \mathrm{~mL}$ Ham's F10, HEPES (8.9 $\mathrm{mmol} / \mathrm{L}$ ), PIPES (10.6 mmol/L), and $N, N$-bis[2-hydroxyethyl]-2aminoethane sulfonic acid ([BES] $11.2 \mathrm{mmol} / \mathrm{L}$ ) supplemented with $10 \%$ fetal calf serum, $\mathrm{CaCl}_{2}(2 \mathrm{mmol} / \mathrm{L})$, glucose $(6.7$ $\mathrm{mmol} / \mathrm{L})$, insulin $(12 \mathrm{U} / \mathrm{L})$, and penicillin/streptomycin $\left(5 \times 10^{4}\right.$ $\mathrm{U} / \mathrm{L}, \mathrm{pH}$ 7.4). After 4 hours of culture, the cells were washed once with rinsing medium and used for experiments. ${ }^{16}$

\section{Uptake of $/^{125} I J T_{3}$ and $/^{125} I / T_{3} S$}

For these studies, cells were cultured as described above. On the same culture dishes, an equal number of wells contained only culture medium (blanks). All incubations with and without cells were performed in triplicate.

Pituitary cells were equilibrated in $0.5 \mathrm{~mL}$ culture medium containing $0.5 \%$ BSA. After equilibration for 30 minutes, the medium was removed and the cells were incubated for 1 hour at $37^{\circ} \mathrm{C}$ with [ $\left.{ }^{125} \mathrm{I}\right] \mathrm{T}_{3}(50,000 \mathrm{cpm}, 50 \mathrm{pmol} / \mathrm{L})$ in $0.25 \mathrm{~mL}$ medium alone or together with 0.01 to $10 \mu \mathrm{mol} / \mathrm{L} \mathrm{T}_{3}$ or $\mathrm{T}_{3} \mathrm{~S}$. The uptake of $\left[{ }^{125} \mathrm{I}\right] \mathrm{T}_{3} \mathrm{~S}(50,000 \mathrm{cpm})$ was measured exactly as for $\left[{ }^{125} \mathrm{I}\right] \mathrm{T}_{3}$,

To allow direct comparison with the hepatocyte experiments, two experiments with pituitary cells were performed in incubation medium where $\mathrm{NaHCO}_{3}$ was replaced by an equimolar amount of HEPES $(8.9 \mathrm{mmol} / \mathrm{L})$, PIPES $(10.6 \mathrm{mmol} / \mathrm{L})$, and BES $(11.2$ $\mathrm{mmol} / \mathrm{L}$ ). As previously described, this did not affect the uptake of $\left[{ }^{125} \mathrm{I}\right] \mathbf{T}_{3}$ by the pituitary cells ${ }^{11}$ (Table 2 ).

After incubation, the medium was removed and the cells were washed with $1 \mathrm{~mL}$ ice-cold saline to remove labeled compounds not bound to the cells. Cells were dissolved in $1 \mathrm{~mL} 0.1 \mathrm{~N} \mathrm{NaOH}$ and were counted for radioactivity in a 16-channel gamma counter (NE 1600, Nuclear Enterprises, Sighthill, Edinburgh, Scotland). The amount of $\left[{ }^{125} \mathrm{I}\right] \mathrm{T}_{3}$ or $\left[{ }^{125}\right] \mathrm{T}_{3} \mathrm{~S}$ taken up by the cells was expressed as a percentage of the dose. The same procedure was applied to the incubations without cells. All results are corrected for the amount of radioactivity retained in the wells without cells.

Hepatocytes were incubated with $\left[{ }^{125} \mathrm{I}\right] \mathrm{T}_{3}$ or $\left[{ }^{1-3} \mathrm{I}\right] \mathrm{T}_{3} \mathrm{~S}$ (both $100,000 \mathrm{cpm} / \mathrm{mL}$ ) at $37^{\circ} \mathrm{C}$ for 1 to 120 minutes in $1 \mathrm{~mL}$ hepatocyte culture medium with $0.5 \%$ BSA instead of fetal calf serum. Further processing was the same as for pituitary cells.

\section{lodide Production}

Aliquots of the incubation medium from the three uptake experiments with hepatocytes (Fig 2) and the two experiments with pituitary cells (Table 2) were chromatographed on Sephadex I.H-20. ${ }^{16}$ Iodide was eluted from the column with $3 \times 1 \mathrm{~mL} 0.1 \mathrm{~N}$ $\mathrm{HCl}$. Subsequently, glucuronides and sulfates (conjugates) were eluted with $8 \times 1 \mathrm{~mL} \mathrm{H}_{2} \mathrm{O}$, and finally the iodothyronines were removed from the column with $3 \times 1 \mathrm{~mL} 50 \%$ ethanol in $0.1 \mathrm{~N}$ $\mathrm{NaOH}$.

\section{Determination of TSH}

TSH levels in the incubation media were measured by radioimmunoassay as previously described. ${ }^{11}$

\section{Analysis of $T_{3} S$}

The purity of the unlabeled $\mathrm{T}_{3} \mathrm{~S}$ preparation was tested by conventional radioimmunoassay with two $T_{3}$ antisera produced in our laboratory (no. 7157 and 7160 ). Both antisera were used in a final dilution of 1:200,000.

\section{Free $T_{3}$ and $T_{3} S$ Concentrations}

Calculation of the free $T_{3}$ and $T_{3} S$ concentrations in the experiments was based on the determination of the free fractions by equilibrium dialysis. ${ }^{17}$ With $0.5 \%$ BSA in the incubation medium, the free $\mathrm{T}_{3}$ fraction amounted to $2.85 \% \pm 0.01 \%(\mathrm{n}=4)$, and the free $T_{3} S$ fraction to $2.12 \%(n=2)$. The free $T_{3} S$ fraction was corrected for the fact that only $60 \%$ of the $\mathrm{T}_{3} \mathrm{~S}$ precipitated with $\mathrm{MgCl}_{2}$. It was further checked by high-performance liquid chromatography that this was not due to the presence of iodide in the $\left[{ }^{125} \mathrm{I}\right] \mathrm{T}_{3} \mathrm{~S}$ preparation.

\section{Materials}

All solutions used for cell isolation and cell culture were obtained from GIBCO Europe (Breda, The Netherlands), with the exception of human serum albumin (Rhone-Poulenc, Amstelveen, The Netherlands). dispase (grade II, Boehringer, Mannheim, Germany), and collagenase (type I, Sigma, St Louis, MO). Culture dishes (48- and 6-well) were purchased from Costar (Cambridge, MA) and Nunc (Roskilde, Denmark), respectively. TRH (Relefact) was obtained from Hoechst, Frankfurt am Main, Germany. $\mathrm{T}_{3}$, PIPES, HEPES, BES, and BSA (fraction V) were purchased from Sigma (St Louis, MO). $\left[3^{\prime}-{ }^{125} \mathrm{IJT}_{3}(3,070 \mu \mathrm{Ci} / \mu \mathrm{g})\right.$ was purchased from Amersham International (Aylesbury, Buckinghamshire, UK). $T_{3} S$ and $\left[{ }^{125} \mathrm{I}\right] \mathrm{T}_{3} S$ were prepared from $\mathrm{T}_{3}$ and $\left[{ }^{125} \mathrm{I}\right] \mathrm{T}_{3}$, respectively, using $\mathrm{ClSO}_{3} \mathrm{H}^{18}\left[{ }^{125} \mathrm{I}\right] \mathrm{T}_{3} \mathrm{~S}$ was purified by $\mathrm{LH}-20$ chromatography, and analysis of the fractions by high-performance liquid chromatography ${ }^{18}$ showed that the preparation consisted of $98 \% \mathrm{~T}_{3} \mathrm{~S}$ and contained less than $2 \%$ iodide. Reagents for the rat TSH radioimmunoassay were kindly provided by the National Institute of Diabetes and Digestive and Kidney Diseases (Bethesda, MD). Sephadex G25 was obtained from Pharmacia (Uppsala, Sweden). All other reagents were of the highest purity available. 


\section{Statistics}

Significances of differences were calculated with Student's $t$ test for unpaired observations. A $P$ value less than .05 was regarded as statistically significant.

\section{RESULTS}

\section{Effects of $T_{3} S$ on TSH Secretion}

Table 1 shows a comparison of the effects of various concentrations of $T_{3}$ and $T_{3} S$ on the TRH-induced TSH secretion by anterior pituitary cells. When TRH was added at a concentration of $0.1 \mu \mathrm{mol} / \mathrm{L}$, TSH release was stimulated by $176 \%(P<.001)$. This effect was reduced by approximately $45 \%$ after preincubation with $1 \mu \mathrm{mol} / \mathrm{L} \mathrm{T}_{3}$ or $\mathrm{T}_{3} \mathrm{~S}\left(P<.001\right.$ for both). The inhibitory effect of $\mathrm{T}_{3}$ on TRH-induced ISH secretion was the same after preincubation with lower concentrations of $T_{3}(0.1$ and $0.01 \mu \mathrm{mol} / \mathrm{L})$. In contrast, the effect of preincubation with $0.1 \mu \mathrm{mol} / \mathrm{L} \mathrm{T}_{3} \mathrm{~S}$ was much smaller $(14 \%, \mathrm{NS})$, and at $0.01 \mu \mathrm{mol} / \mathrm{L} \mathrm{T}_{3} \mathrm{~S}$ the effect was completely absent. An additional experiment was performed where the effects of even lower concentrations of $T_{3}$ and $T_{3} S$ on TRH-induced TSH secretion were compared. TRH-induced $\mathrm{TSH}$ release was inhibited by $62 \%(P<.025$ or less $)$ at $\mathrm{T}_{3}$ concentrations of $0.01,0.1$, and $1.0 \mu \mathrm{mol} / \mathrm{L}$, and by $41 \%(.05<P<.10)$ at a $\mathrm{T}_{3}$ concentration of $0.001 \mu \mathrm{mol} / \mathrm{L}$. The effect of $\mathrm{T}_{3} \mathrm{~S}$ was absent at 0.001 and $0.01 \mu \mathrm{mol} / \mathrm{L}$, and the maximum effect was obtained at a concentration of $1 \mu \mathrm{mol} / \mathrm{L} \mathrm{T}_{3} \mathrm{~S}$ and amounted to $53 \%$ $(P<.025)$.

\section{Effects of $T_{3} S$ on I $^{125} I / T_{3}$ Uptake}

A comparison between the effects of $T_{3}$ and $T_{3} S$ was also made with respect to the uptake of $\left[{ }^{125} \mathrm{I}\right] \mathrm{T}_{3}$ by the pituitary cells. Figure 1 shows the combined results of three experiments. In the first experiment with 300,000 cells per well the control uptake of $\left[{ }^{125} \mathrm{I}\right] \mathrm{T}_{3}$ was $1.62 \% \pm 0.03 \%(\mathrm{n}=3)$, and in the second and third experiments with 500,000 cells per well it was $3.96 \% \pm 0.15 \%(\mathrm{n}=3)$ and $2.39 \% \pm 0.08 \%$ $(\mathrm{n}=5)$. Simultaneous incubation of the cells with $0.01,0.1$, 1 , and $10 \mu \mathrm{mol} / \mathrm{L}$ unlabeled $T_{3}$ reduced the uptake of

Table 1. Effects of $T_{3}$ and $T_{3} S$ on the TRH-Induced Stimulation of TSH Release From Anterior Pituitary Cells

\begin{tabular}{lccc}
\hline \multicolumn{1}{c}{ Experimental Conditions } & TSH Release $(\mathrm{ng})$ & Effect $(\%)$ & $P$ \\
\hline Controls $(14)$ & $2.1 \pm 0.1$ & & \\
$+\mathrm{TRH} 0.1 \mu \mathrm{mol} / \mathrm{L}(14)$ & $5.8 \pm 0.2$ & +176 & $<.001$ \\
$\mathrm{TRH}+\mathrm{T}_{3} 1 \mu \mathrm{mol} / \mathrm{L}(8)$ & $4.1 \pm 0.3$ & +95 & $<.001^{*}$ \\
$\mathrm{TRH}+\mathrm{T}_{3} \mathrm{~S} 1 \mu \mathrm{mol} / \mathrm{L}(9)$ & $3.9 \pm 0.3$ & +86 & $<.001^{*}$ \\
$\mathrm{TRH}+\mathrm{T}_{3} 0.1 \mu \mathrm{mol} / \mathrm{L}(3)$ & $4.3 \pm 0.1$ & +104 & $<.025^{*}$ \\
$\mathrm{TRH}+\mathrm{T}_{3} \mathrm{~S} 0.1 \mu \mathrm{mol} / \mathrm{L}(6)$ & $5.3 \pm 0.2$ & +152 & $\mathrm{NS}^{*}$ \\
$\mathrm{TRH}+\mathrm{T}_{3} 0.01 \mu \mathrm{mol} / \mathrm{L}(6)$ & $4.2 \pm 0.2$ & +100 & $<.001^{*}$ \\
TRH $+\mathrm{T}_{3} \mathrm{~S} 0.01 \mu \mathrm{mol} / \mathrm{L}(6)$ & $5.7 \pm 0.1$ & +171 & $\mathrm{NS}^{*}$ \\
\hline
\end{tabular}

NOTE. Data are the mean \pm SE of three independent experiments, with the number of observations in parentheses. Anterior pituitary cells were cultured for 3 days at a density of $5 \times 10^{5}$ cells $/$ well. The cells were preincubated for 2 hours in the absence or presence of $T_{3} \mathbf{1 0 . 0 1}$ to 1 $\mu \mathrm{mol} / \mathrm{L})$ or $\mathrm{T}_{3} \mathrm{~S}(0.01$ to $1 \mu \mathrm{mol} / \mathrm{L})$. Then they were incubated with TRH $(0.1 \mu \mathrm{mol} / \mathrm{L})$ for 2 hours with or without the additions indicated.

* $P$ values calculated compared with the addition of TRH alone

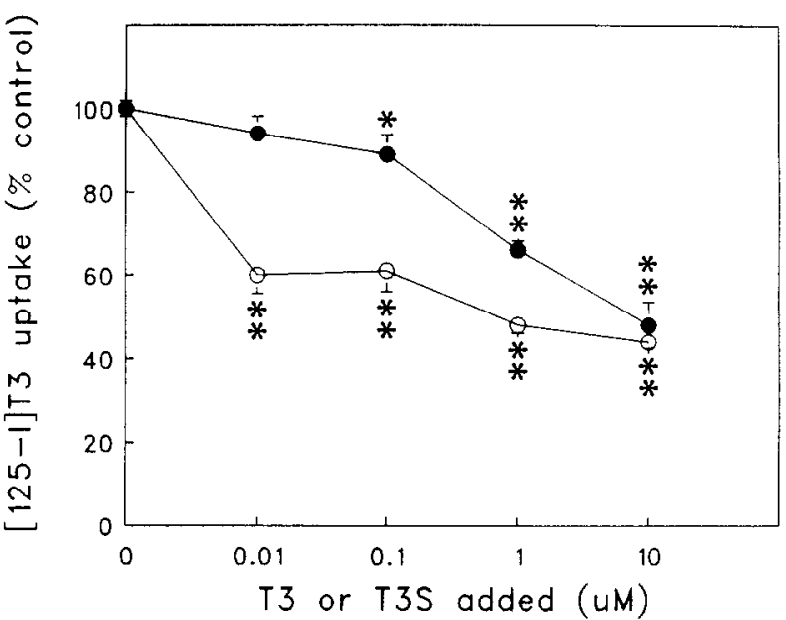

Fig 1. Effects of unlabeled $(O) \mathrm{T}_{3}$ and $(0) \mathrm{T}_{3} \mathrm{~S}$ on the uptake of [125]] $\mathrm{T}_{3}$ by anterior pituitary cells. The cells were cultured for 3 days at a density of 3 to $5 \times 10^{5}$ cells / well. After equilibration, the cells were incubated for 1 hour with [ $\left.{ }^{125}\right] \mathrm{T}_{3}(50,000 \mathrm{cpm})$ with various concentrations of unlabeled $T_{3}$ or $T_{3} S$. Data represent the mean $\pm S E$ of three to nine observations from three independent experiments. Significances of differences were calculated as compared with the controls $(100 \%)$ : $* P<.025, * * P<.001$.

$\left[{ }^{125} \mathrm{I}_{\mathrm{T}}\right.$ by $40 \% \pm 4 \%(P<.001), 40 \% \pm 5 \%(P<.001)$, $52 \% \pm 2 \%(P<.001)$, and $56 \% \pm 1 \%(P<.001)$, respectively. When $\mathrm{T}_{3} \mathrm{~S}$ was added at concentrations of $0.01,0.1,1$, or $10 \mu \mathrm{mol} / \mathrm{L},\left[{ }^{125} \mathrm{I}_{3} \mathrm{~T}_{3}\right.$ uptake was reduced by $6 \% \pm 4 \%$ (NS), $11 \% \pm 4 \%(P<.025), 34 \% \pm 2 \%(P<.001)$, and $52 \% \pm 5 \%(P<.001)$, respectively.

\section{Uptake of $\left.\right|^{125} I J T_{3} S$ by Pituitary Cells and Hepatocytes}

In four experiments with 500,000 cells per well, the uptake of $\left[{ }^{125} \mathrm{I}\right] \mathrm{T}_{3} \mathrm{~S}$ by pituitary cells was compared with that of $\left.{ }^{125} \mathrm{I}\right] \mathrm{T}_{3}$ (Table 2). After 1 hour of incubation the uptake of $\left.{ }^{125} \mathrm{I}\right] \mathrm{T}_{3} \mathrm{~S}$ was less than $0.1 \%$, whereas the mean uptake of $\left[{ }^{125} \mathrm{I}\right] \mathrm{T}_{3}$ amounted to $3.0 \% \pm 0.4 \%$ (Table 2). In contrast, both $\left[{ }^{125} \mathrm{I}\right] \mathrm{T}_{3} \mathrm{~S}$ and $\left[{ }^{125} \mathrm{I}\right] \mathrm{T}_{3}$ were taken up by hepatocytes (Fig 2A), although the uptake of $\left[{ }^{125} \mathrm{I}\right] \mathrm{T}_{3}$ was roughly fourfold greater than that of $\left[{ }^{125} \mathrm{I}\right] \mathrm{T}_{3} \mathrm{~S}$. The uptake of both compounds reached a maximum value between 0.5 and 1 hour of incubation, and then declined slightly. As can be seen from Fig $2 B$, both $T_{3}$ and $T_{3} S$ were deiodinated in hepatocytes, and iodide production from $\left[{ }^{125} \mathrm{I}_{\mathrm{T}} \mathrm{S} S\right.$ was at

Table 2. Comparison of the Uptake of $\left[{ }^{125} \mid\right] T_{3}$ and $\left.\left[{ }^{125}\right]\right] T_{3} S$ in Anterior Pituitary Cells

\begin{tabular}{ccc}
\hline Experiment No. & {$\left[{ }^{25} \mid \mathrm{T}_{3}\right.$ Uptake (\% dose) } & {$\left[{ }^{125}\right] \mathrm{T}_{3}$ S Uptake (\% dose) } \\
\hline 1 & $2.96 \pm 0.02$ & $0.01 \pm 0.04$ \\
2 & $2.64 \pm 0.09$ & $0.07 \pm 0.02$ \\
3 & $2.34 \pm 0.13$ & $0.00 \pm 0.05$ \\
4 & $3.96 \pm 0.15$ & $0.09 \pm 0.06$ \\
\hline
\end{tabular}

NOTE. Data represent the mean \pm SE of triplicate determinations. Anterior pituitary cells were cultured for 3 days at a density of $5 \times 10^{5}$ cells/well. Experiments 1 and 2 were performed in incubation medium containing $\mathrm{NaHCO}_{3}$, and experiments 3 and 4 in incubation medium containing HEPES, BES, and PIPES. The cells were equilibrated for 30 minutes in incubation medium and then incubated for 1 hour with $\left[{ }^{125}\right] T_{3}$ or $\left.\left[{ }^{125}\right]\right] T_{3} S$ (both $50,000 \mathrm{cpm} / 0.25 \mathrm{~mL}$ ). 

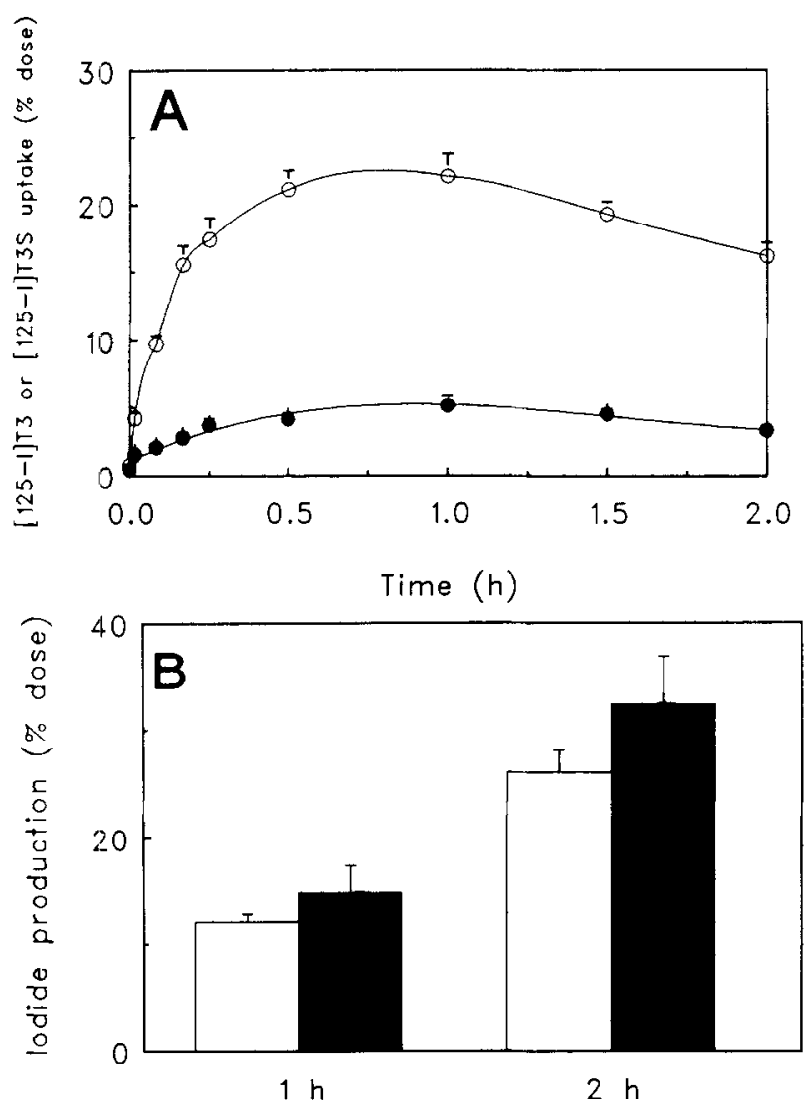

Fig 2. Time course of the $(A)$ uptake of $(O)\left[{ }^{125} \mid\right]_{3}$ and $\left.\left.(-)^{125}\right]\right]_{3} S$ and (B) iodide production by primary cultures of hepatocytes. Hepatocytes were incubated for periods varying from 1 minute to 2 hours with [125] $]_{3}$ or $\left.\left[{ }^{125}\right]\right] \mathrm{T}_{3} \mathrm{~S}$ (both $100,000 \mathrm{cpm} / \mathrm{mL}$ ). lodide production after 1 and 2 hours of incubation was measured in the media by LH-2O chromatography. Data represent the mean \pm SE of nine observations from three independent experiments. $(\square$ ) lodide production from $\left.\left[{ }^{125}\right]\right]_{3} ;(\square)$ iodide production from $\left[{ }^{125} 1\right] \mathrm{T}_{3} \mathrm{~S}$.

least as high as that from $\left[{ }^{125} I\right] T_{3}$. Furthermore, iodide production from $\mathrm{T}_{3}$ and $\mathrm{T}_{3} \mathrm{~S}$ doubled when the incubation time was prolonged from 1 to 2 hours. In the same 1-hour period, the mean conjugate formation from $\left[{ }^{125} \mathrm{I}\right] \mathrm{T}_{3}$ was $4.7 \% \pm 0.8 \%$ (not shown). There was no production of unconjugated $\mathrm{T}_{3}$ from $\left[{ }^{125} \mathrm{I}\right] \mathrm{T}_{3} \mathrm{~S}$ by hepatocytes during the course of the experiment (not shown).

To determine if pituitary cells also metabolized $\mathrm{T}_{3}$ and $T_{3} S$, incubation media from the last two experiments shown in Table 2 were analyzed for iodide production. Neither in the media from the pituitary cells incubated with $\left[{ }^{125} \mathrm{I}\right] \mathrm{T}_{3}$ nor in those from [ $\left.{ }^{125} \mathrm{I}\right] \mathrm{T}_{3} \mathrm{~S}$ incubations was iodide detectable. After incubation with $\left[{ }^{125} \mathrm{I}\right] \mathrm{T}_{3}$, no conjugates were detected, and $95 \%$ of the radioactivity appeared in the iodothyronine fraction. In the case of $\left[{ }^{125} \mathrm{I}^{1} \mathrm{~T}_{3} \mathrm{~S}, 90 \%\right.$ to $95 \%$ of the radioactivity was found in the conjugate fraction, and no radioactivity was found in the iodothyronine fraction (not shown).

\section{Purity of Unlabeled $T_{3} S$}

Finally, the amount of $T_{3}$ present in the unlabeled $T_{3} S$ preparation was determined by radioimmunoassay with two different antisera, showing that the $\mathrm{T}_{3} \mathrm{~S}$ preparation contained $0.25 \% \mathrm{~T}_{3}$. Incubation medium with $1 \mu \mathrm{mol} / \mathrm{L} \mathrm{T}_{3} \mathrm{~S}$ contained $2.49 \mathrm{nmol} / \mathrm{L} \mathrm{T}_{3}$ before incubation with cells and $2.08 \pm 0.02(\mathrm{n}=3) \mathrm{nmol} / \mathrm{L} \mathrm{T}_{3}$ after incubation with cells.

\section{DISCUSSION}

The results of the present study indicate that $T_{3} S$ does not play a significant role in the suppression of TSII secretion in pituitary cells in vitro. Furthermore, our results suggest essential differences in the metabolic handling of $\mathrm{T}_{3}$ and $\mathrm{T}_{3} \mathrm{~S}$ by pituitary cells and hepatocytes.

LoPresti et al $^{7}$ suggested that $T_{3} S$ might play a role in the suppression of TSH secretion during NTI. This hypothesis seemed already somewhat weakened by their own observation that infusion of $\mathrm{T}_{3} \mathrm{~S}$ in healthy volunteers did not result in decreased levels of serum TSH. On the other hand, the serum level of $T_{3} S$ achieved during the infusion was not measured, and the lack of effect of $T_{3} S$ could be due to the low calculated $\mathrm{T}_{3} \mathrm{~S} / \mathrm{T}_{3}$ ratio $(46 \%)$.

Although $1 \mu \mathrm{mol} / \mathrm{L} \mathrm{T}_{3} \mathrm{~S}$ was as effective as $1 \mu \mathrm{mol} / \mathrm{L} \mathrm{T}_{3}$ in suppressing the TRH-induced TSH secretion in our cell culture, this effect can simply be explained on the basis of a slight contamination of the $T_{3} S$ preparation with $T_{3}$. The amount of $\mathrm{T}_{3}$ in the unlabeled $\mathrm{T}_{3} \mathrm{~S}$ preparation was $0.25 \%$, and hence, $1 \mu \mathrm{mol} / \mathrm{L} \mathrm{T}_{3} \mathrm{~S}$ will roughly contain $2.5 \mathrm{nmol} / \mathrm{L}$ $\mathrm{T}_{3}$. This idea was confirmed by the experiment where the effect of $1 \mu \mathrm{mol} / \mathrm{L} \mathrm{T}_{3} \mathrm{~S}$ on TRH-induced TSH secretion was found to correspond to a value (53\%) just between 1 $\mathrm{nmol} / \mathrm{L} \mathrm{T}_{3}(41 \%)$ and $10 \mathrm{nmol} / \mathrm{L} \mathrm{T}_{3}(62 \%)$.

The effect of unlabeled $\mathrm{T}_{3} \mathrm{~S}$ on the uptake of $\left[{ }^{125} \mathrm{I}\right] \mathrm{T}_{3}$ by pituitary cells was dose-dependent, and was still lower ( $34 \%$ inhibition) when $\mathrm{T}_{3} \mathrm{~S}$ was added at a concentration of $1 \mu \mathrm{mol} / \mathrm{L}$ as compared with the effect of $10 \mathrm{nmol} / \mathrm{L} \mathrm{T}_{3}$ ( $40 \%$ inhibition). In our previous study, ${ }^{11}$ it was observed that addition of $1 \mathrm{nmol} / \mathrm{L} \mathrm{T}_{3}$ reduced the uptake of $\left[{ }^{125} \mathrm{I}\right] \mathrm{T}_{3}$ by approximately $29 \%$. Thus, the effects of $\mathrm{T}_{3} \mathrm{~S}$ on $\left[{ }^{125} \mathrm{I}\right] \mathrm{T}_{3}$ uptake are also compatible with a contamination of the $\mathrm{T}_{3} \mathrm{~S}$ preparation with $\mathrm{T}_{3}(<1 \%)$. Our results are also in line with those of Spaulding et al, ${ }^{8}$ who apparently used more purified $\mathrm{T}_{3} \mathrm{~S}$ and found no displacement of $\left[{ }^{125} \mathrm{I}\right] \mathrm{T}_{3}$ from the nuclear receptors in the growth hormone-producing cell line $\mathrm{GH}_{4} \mathrm{C}_{\mathrm{I}}$ in the concentration range of 0.001 to $1 \mu \mathrm{mol} / \mathrm{L}$ $\mathrm{T}_{3} \mathrm{~S}$.

The explanation that the effect of high concentrations of $\mathrm{T}_{3} \mathrm{~S}$ on TRH-induced TSH secretion or $\left[{ }^{125} \mathrm{I}\right] \mathrm{T}_{3}$ uptake is due to contamination of the $T_{3} S$ preparation with $T_{3}$ is also supported by our observation that $\left[{ }^{125} \mathrm{I}\right] \mathrm{T}_{3} \mathrm{~S}$ itself was only poorly taken up by the pituitary cells. This was concluded from a series of experiments where a significant amount of $\left.{ }^{125} \mathrm{I}\right] \mathrm{T}_{3}$, added at the same radioactive and molar concentration as $\left.{ }^{125} \mathrm{I}\right] \mathrm{T}_{3} \mathrm{~S}$, was taken up by the pituitary cells. In contrast, both $\left[{ }^{125} \mathrm{I}\right] \mathrm{T}_{3}$ and $\left[{ }^{125} \mathrm{I}\right] \mathrm{T}_{3} \mathrm{~S}$ were taken up by hepatocytes, although the uptake of $\left[{ }^{125} \mathrm{I}\right] \mathrm{T}_{3}$ was roughly fourfold higher than that of $\left[{ }^{125} \mathrm{I}\right] \mathrm{T}_{3} \mathrm{~S}$. On the other hand, despite this difference in uptake, iodide production from $\left[{ }^{125} \mathrm{I}\right] \mathrm{T}_{3} \mathrm{~S}$ was at least as high as that from $\left[{ }^{125} \mathrm{I}\right] \mathrm{T}_{3}$. This indicated that $T_{3} S$ and $T_{3}$ (after preceding sulfation ${ }^{19}$ ) were deiodinated followed by efflux of ${ }^{125} \mathrm{I}^{-}$from the liver cells. These results also confirmed the previous observation that 
$\mathrm{T}_{3} \mathrm{~S}$ is a preferred substrate for the liver type I deiodinase, being deiodinated successively in the inner and outer ring. ${ }^{12.19}$ During the 2 hours of the experiments, no unconjugated $T_{3}$ was detectable in the media from hepatocytes incubated with $\left[{ }^{125} \mathrm{I}\right] \mathrm{T}_{3} \mathrm{~S}$. This seems to be in contrast to the observations of Kung et al, ${ }^{20}$ who reported $1 \%$ hydrolysis of $\mathrm{T}_{3} \mathrm{~S}$ per hour in isolated hepatocytes. The reason for this the presence of $\mathrm{T}_{3} \mathrm{~S}$ in the micromolar range (7 to 50 $\mu \mathrm{mol} / \mathrm{L}$ ) in the study by Kung et al, ${ }^{20}$ which is far above the $K_{m}$ of the type I deiodinase for $\mathrm{T}_{3} \mathrm{~S}\left(4.6 \mu \mathrm{mol} / \mathrm{L}^{21}\right)$, resulting in saturation of the deiodination pathway. In our experiments, the $T_{3} S$ concentration was in the picomolar range.

Although the anterior pituitary is generally regarded as an organ with a low type I deiodinase activity, ${ }^{22}$ extremely rapid deiodination of $\left[{ }^{125} \mathrm{I}\right] \mathrm{T}_{3} \mathrm{~S}$ and efflux of ${ }^{125} \mathrm{I}^{-}$could theoretically account for the observation that cellular uptake of $\left[{ }^{125} \mathrm{I}\right] \mathrm{T}_{3} \mathrm{~S}$ was hardly detectable. It was recently reported that the posterior pituitary, ${ }^{23}$ like the brain, ${ }^{24}$ contains type III deiodinase that would deiodinate $T_{3}$. This discrepancy might be that hepatocytes were incubated in

reaction would only be detectable by ${ }^{125} \mathrm{I}^{-}$production, if the inner-ring deiodination by type III deiodinase is followed by outer-ring deiodination. Furthermore, $T_{3} S$ is not a substrate for the type III deiodinase. ${ }^{25}$ The LH-20 chromatography performed in the same way as for the hepatocyte experiments showed no ${ }^{125} \mathrm{I}^{-}$production from $\left[{ }^{125} \mathrm{I}\right] \mathrm{T}_{3} \mathrm{~S}$ or from $\left[{ }^{125} \mathrm{I}\right] \mathrm{T}_{3}$ during the hour the experiment lasted.

Taken together. our results strongly suggest that relative to $\mathrm{T}_{3}, \mathrm{~T}_{3} \mathrm{~S}$ is poorly taken up by the pituitary gland. In addition, it seems that $T_{3} S$ is not hydrolyzed in this tissue, and consequently the biological effects of $T_{3} S$ on the euthyroid pituitary gland are minimal.

\section{ACKNOWLEDGMENT}

The material used in the TSH assay was kindly provided by the National Hormone and Pituitary Program of the National Institute of Diabetes and Digestive and Kidney Diseases (Bethesda, MD). We thank H. van Toor, H.F. Bernard, E.P.C.M. Moerings, and A.M.P. Tempelaars for skillful technical assistance.

\section{REFERENCES}

1. Roche J, Michel R: On the peripheral metabolism of thyroid hormones. Ann NY Acad Sci 86:454-468, 1960

2. Roche J, Michel R, Closon J, et al: Sur le métabolisme du sulfoconjugué de la 3,5,3'-triiodothyronine chez le rat. Biochim Biophys Acta 38:325-332, 1960

3. Visser TJ, van Buuren JCJ, Rutgers M, et al: The role of sulfation in thyroid hormone metabolism. Trends Endocrinol Metab 1:211-218, 1990

4. Vagenakis AG, Burger A, Portnay GI, et al: Diversion of peripheral thyroxine metabolism from activating to inactivating pathways during complete fasting. J Clin Endocrinol Metab 41:191194,1975

5. Spencer CA, Lum SMC, Wilber JF, et al: Dynamics of serum thyrotropin and thyroid hormone changes in fasting. J Clin Endocrinol Metah 56:883-888, 1983

6. Chopra IJ, Wu S-Y, Chua Teco GN, et al: A radioimmunoassay for measurement of 3,5,3'-triiodothyronine sulfate: Studies in thyroidal and non-thyroidal diseases, pregnancy and neonatal life. J Clin Endocrinol Metab 75:189-194, 1992

7. LoPresti JS, Mizuno L. Nimalysuria A, et al: Characteristics of 3,5,3'-triiodothyronine sulfate metabolism in euthyroid man. $\mathbf{J}$ Clin Endocrinol Metab 73:703-709, 1991

8. Spaulding SW, Smith TJ, Hinkle PM, et al: Studies on the biological activity of triiodothyronine sulfate. J Clin Endocrinol Metab 74:1062-1067, 1992

9. Santini F, Chopra IJ, Wu S-Y, et al: Metabolism of 3,5,3'triiodothyronine sulfate by tissues of the fetal rat: A consideration of the role of desulfation of $3,5,3^{\prime}$-triiudothyronine sulfate as a source of $T_{3}$. Pediatr Res 31:541-544, 1992

10. Santini F, Hurd RE, Lee B, et al: Thyromimetic effects of $3,5,3^{\prime}$-triiodothyronine sulfate in hypothyroid rats. Endocrinology 133:105-110, 1993

11. Everts ME, Docter R, van Buuren JCJ, et al: Evidence for carrier-mediated uptake of triiodothyronine in cultured anterior pituitary cells. Endocrinology 132:1278-1285, 1993

12. Eelkman Rooda SJ, Otten MH, van Loon MAC, et al: Metabolism of triiodothyronine in rat hepatocytes. Endocrinology 125:2187-2197, 1989

13. Oosterom R, Verleun T, Lamberts SWJ: Basal and dopafects of culture conditions. Mol Cell Endocrinol 29:197-212, 1983

14. Oosterom R, Verleun T, Zuyderwijk J, et al: Growth hormone secretion by cultured rat anterior pituitary cells. Effects of culture conditions and dexamethasone. Endocrinology 113:735741,1983

15. Krenning EP, Docter R, Bernard HF, et al: Active transport of triiodothyronine $\left(T_{3}\right)$ into isolated liver cells. FEBS Lett 91:113-116, 1978

16. Docter R, Krenning EP, Bernard HF, et al: Inhibition of uptake of thyroid hormone into rat hepatocytes by preincubation with $N$-bromoacetyl-3-3',5 triiodothyronine. Endocrinology 123 : 1520-1525, 1988

17. Sterling K, Brenner MA: Free thyroxine in human serum: Simplified measurement with the aid of magnesium precipitation. $J$ Clin Invest 45:153-163, 1966

18. Mol JA, Visser TJ: Synthesis and some properties of sulfate esters and sulfamates of iodothyronines. Endocrinology 117:1-7. 1985

19. Otten MH, Mol IA, Visser TI: Sulfation preceding deiodination of iodothyronines in rat hepatocytes. Science 221:81-84, 1983

20. Kung M-P, Spaulding SW, Roth JA: Desulfation of 3,5,3'triiodothyronine sulfate by microsomes from human and rat

21. Visser TJ, Mol JA, Otten MH: Rapid deiodination of triiodothyronine sulfate by rat liver microsomal fraction. Endocrinology 112:1547-1549, 1983

22. Köhrle J, Hesch RD, Leonard JL: Intracellular pathways of iodothyronine metabolism, in Braverman LE, Utiger RD (eds): The Thyroid (ed 6). Philadelphia, PA, Lippincott, 1991, pp 144-189

23. Tanaka K, Shimatsu A, Imura H: Iodothyronine 5-deiodinase in rat posterior pituitary. Biochem Biophys Res Commun 188:272-277, 1992

24. Visser TJ, Schoenmakers CHH: Characteristics of type III iodothyronine deiodinase. Acta Med Austriaca 19:18-21, 1992

25. Santini F, Hurd RE, Chopra IJ: A study of metabolism of deaminated and sulfoconjugated iodothyronines by rat placental iodothyronine 5-monodeiodinase. Endocrinology 131:1689-1694, 1992 mine-inhibited prolactin secretion by anterior pituitary cells: Eftissues. Endocrinology 122:1195-1200, 1988 